ISSN 1014-4874

DOI : http://dx.doi.org/10.4314/rj.v27i1.5

\title{
Integrating ICT in Agriculture for Knowledge-Based Economy
}

Ms. Punitha Lakshmi Balraj ${ }^{1}$

Ms. S.M. Pavalam ${ }^{2}$

${ }^{1}$ Assistant Lecturer - Business Information Technology, Department of Management, Faculty of Economics and Management, National University of Rwanda, HUYE, RWANDA. bplakshmi@nur.ac.rw.

${ }^{2}$ Lecturer - Business Information Technology, Department of Management, Faculty of Economics and Management, National University of Rwanda, HUYE, RWANDA.

spavalam@nur.ac.rw.

\begin{abstract}
Rwanda with its embrace to knowledge-based economy, having nearly $80 \%$ of agriculture -based livelihoods, demands the integration of ICT knowledge with agriculture. Already projects such as Agriculture Management Information System (AMIS), and e-Soko (which means electronic marketing) - which provides farmers with the price decision making tools enlightens the path to socio-economic development through agriculture. This paper explores the impact of these systems by analyzing the data collected from Executives (initiators of the Project), Service Providers (Medium Level who helps to realize the project) and farmers (ultimate stakeholders).The bottlenecks identified were ICT illiteracy among farmers, nonavailability of relevant and localized content, lack of awareness about the technology and lack of willingness to embrace the technology at the side of farmers, The technical bottlenecks were the contents of the website that are static and needs to be changed as an interactive one and the localization of contents of the website. Having explored all the bottlenecks, necessary infrastructure and technology accessibility, the possible factors for enhancing the technology usage are recommended.
\end{abstract}

Key Words: ICT, e-Soko, AIMS, Agriculture

\section{Introduction}

Agriculture, as aged as human race itself, is a main occupation of more than 70 percent of people all over the world. (Lipton 2002; UN 2001). Eradicating extreme poverty and hunger, as the very first Millennium Development Goal (MDG), the development of any country depends on how the country is using its resources optimally in achieving this goal. About 70 percent of the MDGs' target group lives in rural areas, particularly in Asia and Africa, and for most of the rural poor, agriculture is a critical component in the successful attainment of the MDGs (Rosegrant. 2006). 
The transformation of the decade into information age, the industry based economy into Knowledge-based economy, the vast growth of ICT tools in all walks of human life, has made it mandatory, that those who have the access to ICTs are the benefiters, those who lack shall become the losers. Thus this perilous aspect of information access, results in developing another crucial race of haves and have-nots which is again has its deep impact in country's Development.

Rwanda, a country of thousand hills, is a fast developing African country. This small landlocked country is a frontier to the world in many paths, namely the frontier in having nearly $50 \%$ women as decision makers in Parliament, the country which adopts zero corruption policy and the fastest growing African country in adoption of ICT in all its sectors drawing a huge number of Foreign Direct Investment (FDI) Still, being a country which has a long war-history, and the latest 1994 Genocide, the infrastructure facilities are in the fast growing stage, economy is getting stabilizing.

Rwanda is a land-locked country of approximately 9.3 million inhabitants and an annual population growth rate of $2.8 \%$ (EIU Rwanda report, May 2008) The country is just over 26,000 square kilometers and has the highest population density in Africa (CIA, Rwanda The World Factbook 2008). The country is one of the poorest in the world, with a GDP per capita of approximately \$230 (Government of Rwanda, Health Sector Strategic Plan 2005-2009). With $37.6 \%$ as the GDP composition by agriculture sector, the country depends on agriculture sector for its development (New Agriculturist - Country profile - Rwand 2010).

The country ranks 161 out of 177 countries on the United Nations Human Development Index (2008), Sixty percent of the population lives under \$1 per day, sixty-six percent is under the age of twenty years, and $83 \%$ is rural dwelling (Ministry of Health, Government of Rwanda, 2010).

Agriculture is a dominant economic activity for the majority of population of rural Rwanda. Agricultural development is considered as a key pillar in growth and is significantly reducing poverty in the country (MINAGRI, 2010).

There are many initiatives like Management Information System for Agriculture(AMIS), e-Soko from the Government of Rwanda, are helping in a larger extent to extract the benefits of ICT and in the progress to achieve MDG's.

Number of studies has been made by Government of Rwanda, independent researchers and by the Various funding agencies on agriculture sector and Rwanda's economic and social development through agriculture. Studies carried out by Ministry of Agriculture, Government of Rwanda in 
collaboration with Ministry of Economics and Finance and such as Agricultural Survey (2006) shows the clear figures on how important agriculture sustainability is to the Rwandan people. The Market Survey Report on Project Market Information System (AMIS) shows the commitment of the Government of Rwanda in helping the stakeholders of agriculture in their pricing decisions. Other studies include Agriculture and Poverty in Rwanda: A Comparative Analysis of the EICV1, EICV2, and LRSS Surveys. (Loveridge eds, [2007]) and"Healing Wounds" - a recent report from the Consultative Group on International Agriculture Research (CGIAR) shows the vital role of Agricultural development in Rwanda's recovery after genocide. The website of Ministry of Agriculture, Government of Rwanda shows the importance and execution of e-Soko project. Also Agricultural Statistics of Rwanda, gives the background information about e-Soko project.

Projects sponsored by UNDP, UNIFEM, World Bank have been validated and published reports on Rwanda's ICT status and implementation. As a frontier in development activities with ICT means, Government of Rwanda itself has a dynamic website and other government affiliated websites Rwanda Development Gateway (RDG) and Rwanda Information and Technology Authority (RITA) provides enough information on the ICT infrastructure development and utilization. The Government has its own documentary on "ICT in Rwanda" which gives clear idea of ICT based development initiatives of the government of Rwanda. Governments ICT policies NICI I \& NICI II, Vision 2020 documents, World Bank's publication "Rwanda ICT at a Glance", provides the clear picture about the ICT infrastructure development, and e-readiness of the country.

Apart from these independent researches, in the current study, the researches in the form of focused group discussion with the executive level officials of the e-Soko and AMIS project, Government of Rwanda, discussions and interviews with the service provider MTN mobile shows the impact of these technologies and usage of these technologies. And the Focused Group Discussions with farmers who were associated with farmer associations for the agriculture products like Banana, sorghum, coffee and tea provides the need for creating awareness about these ICT led initiatives to the public. With these background, this paper explores the impact of these technology led initiatives in Agriculture in Rwanda and proposes the possible enhancement, which could be adapted in the near future in order to increase penetration to the public.

\section{Achievements in ICT in Rwanda}

Rwanda in its realization of 2020 Vision, MGDs, and Country's Econmic Development and Poverty Reduction Strategy 2012 (EDPRS 2012), fully depends on ICTs for its development and so, it has adopted Knowledge- 
based economy and ICT intensive development. After having fully wrenched of all its resources and infrastructures during 1994, this country's development in ICT sector is astonishing. Mobile phone and internet penetration rate is more than $1000 \%$ in East African countries in the last decade (Figure 1). Rwanda is having comparatively high internet penetration in the last decade than any other East African country, which was the appreciable initiative of the government in linking most of the offices and officers and organizations through internet connectivity.

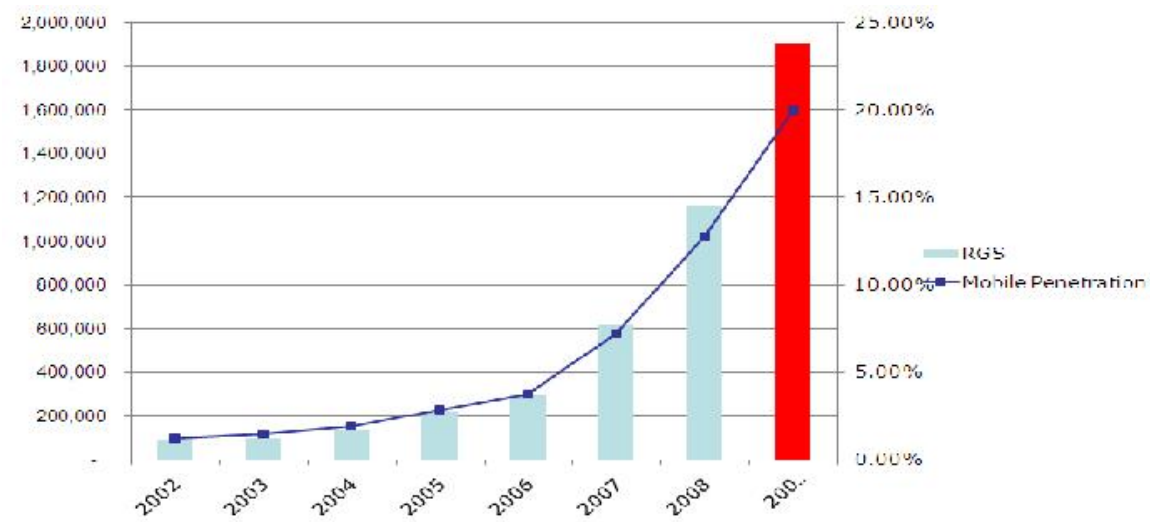

Figure 1: MTN Internet and Mobile Penetration at Rwanda

Due to ICT market liberalization, the monopoly spirit is broken with participation of different companies in the market, and so the access cost has come down thus making the common people able to own and access the ICT services. The government has invested heavily in the ICT sector in the past decade, which shows the development and scope in this sector. According to Rwanda Development Board, (2007), the investment on ICT sector of Rwanda during 2006, was estimated by $23 \%$. ICT has a significant impact to socio economic performance to the country. This trend has also a positive impact to the economic growth, the ICT sector contribution to the GDP was $2.7 \%$, where Rwanda comes as the second top all over the East African region (Usengumukiza, 2009).

In the framework of Vision 2020, Government of Rwanda is committed to use ICT in most of its activities in order to facilitate the rapid socioeconomic development. Also it has the strong ICT policies such as National communication and Infrastructure policies known as NICI I, and NICI II. Several ICT related government projects such as Kigali Metropolitan Network, Rwanda National Backbone Project, Regional Communication Infrastructure project, National Data Centre, Kigali ICT Park, and eRwanda are on the fast implementation phase. The EASSY Project to which Rwanda is integrated will contribute significantly to Rwanda's integration 
to the world economy. The implementation of this project will make Rwanda as the regional ICT hub for East African region (Usengumukiza, 2009).

Through NICI I, NICI II programmes, most of activities are now based on E-Sector, some of them are listed as follows :

E-Education : One Laptop per Child project: 100,000 computers distributed to different primary schools, E-Schools in secondary school, Regional ICT Training and Research Center (RITC), facilitation of ELearning and Distance Learning, formation of Rwanda Education and Research Network and GIS, Rwanda Development Gateway are the ICT initiative in education sector.

E-Health: An open-source Medical Records System that tracks patientlevel data; TracPlus and TRACnet- Monthly monitoring of infectious diseases including HIV/AIDS, TB, and Malaria; Telemedicine Information and communication technology (ICT) used to deliver health and healthcare services; Mobile e-Health- use of mobile technology in improving health delivery in Rwanda; Health Management Information Systems (HMIS) - systems that integrate data collection processing, reporting, and use of the information for programmatic decision-making.

E-Government : Fiber optic Installation, connectivity of a good number of schools, hospitals and other public institutions; Public Access Channels (12 Tele centers- Desks are already operational); Kigali ICT Center; Smart National Cards, ID, E-business

E-Agriculture: Agricultural Management Information System (AMIS) is an exchange platform for all stakeholders of the agricultural and livestock sector; e-Soko project seeks to empower farmers to enable them make more informed market pricing decisions and ultimately more successful farming

e-Soko : An Introduction: eRwanda Project on Market Prices called eSoko originated from Rwandan name Soko which means Market and "therefore electronic Market".This initiative is a response to the explosive growth of cellular services in Africa which presents a new opportunity to link producers to better markets. More transparent markets using mobile technology can reduce the people, time and cost involved in transactions, and create new opportunities for buyers and traders. (Wikipedia 2010). The eRwanda Project, a World Bank funded ICT development project being implemented by the Rwanda Information Technology Authority (RITA) with the use of ICTs through its e-Soko Project that seeks to empower farmers to enable them make more informed market pricing decisions and ultimately more successful farming. This Agricultural Market Pricing Information System (AMIS) will also significantly enhance the Ministry of 
Agriculture - MINAGRI's interaction with the farmers and traders as well as the planning function.

The price collection system involves daily price collection of 47 commodities in 41 markets throughout the country (Project Market Information System, 2007). While initially intended as a full system for providing critical information for private sector traders and producers, the system specializes in price recording and reporting. Analysis and reports have focused on twelve key consumption commodities: maize, sorghum, Irish potatoes, sweet potatoes, cassava, cooking bananas, beans, garden peas, groundnuts, cabbages, tomato and onion. The data have primarily been used for analytical purposes in the public sector, rather than for private sector needs.

The eRwanda Project provides training to the farmers on the use and maintenance of the e-SOKP System equipment in order to sustain the new communication channels that will have been introduced by the system. For farmers without mobile phones, village phones can be used to access the prices. The field staff employed by MINAGRI to collect this information are equipped with smart phones to collect and enter the pricing information in the databases.

\section{e-Soko functional Framework}

The overall architecture of the system is built with a Microsoft SQL 2005 Database and a Java-based middleware built on Voxiva's Mobile Solution Framework to handle J2ME for mobile application for data gathering, .NET for web interface, an Interactive Voice Recognition technology and an SMS handling application (Clement Uwajeneza, 2010). 


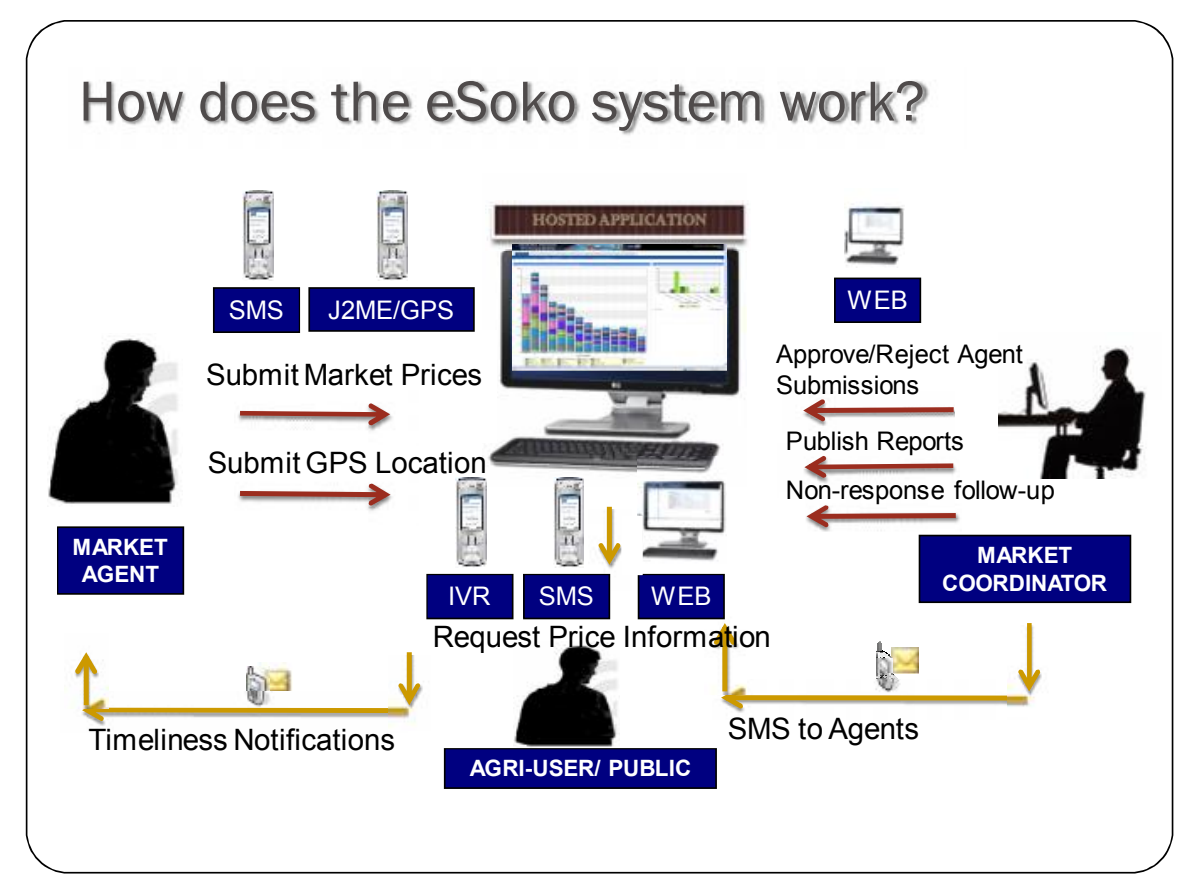

Figure 2: Functional Framework of e-Soko

Source: Clement Uwajeneza \& Emmanuel Kabahizi (2010), Development of a framework for the strengthening of market information systems in Rwanda,

A data submission module, allows the data entry using an web-based interface, a mobile phone application or interactive voice recognition. Market agency who is collecting market price information of the commodities enters the information data to this web-based interface directly with his/her mobile phone, which is then approved by the market coordinator and then is ready for the publication. Once the public or the middleman using their mobile phone which is registered for this service sends a SMS with the commodity name and market name gets the price information. There are additional provisions for adding new markets and new commodities.

\section{e-Soko - Technology}

The farmer is supposed to sign-up and configure his/her mobile for exploiting the benefits of e-Soko so that market prices of the commodities for which he/she has asked for will be supplied to him/her automatically through SMS to the concerned. Apart from the prices, if needed an special alert about the commodity will also be supplied, which will facilitate the farmer with a decision making in selecting the optimum market price. This facility is originally offered through website www.esoko.gov.rw, which has the additional features about the latest market prices, monthly price reports, Weekly agricultural news province and district wise, codes and 
corresponding market details. A provision for user name and password provides the unique way of personalization of the market and commodity details. A snapshot of the website is presented below

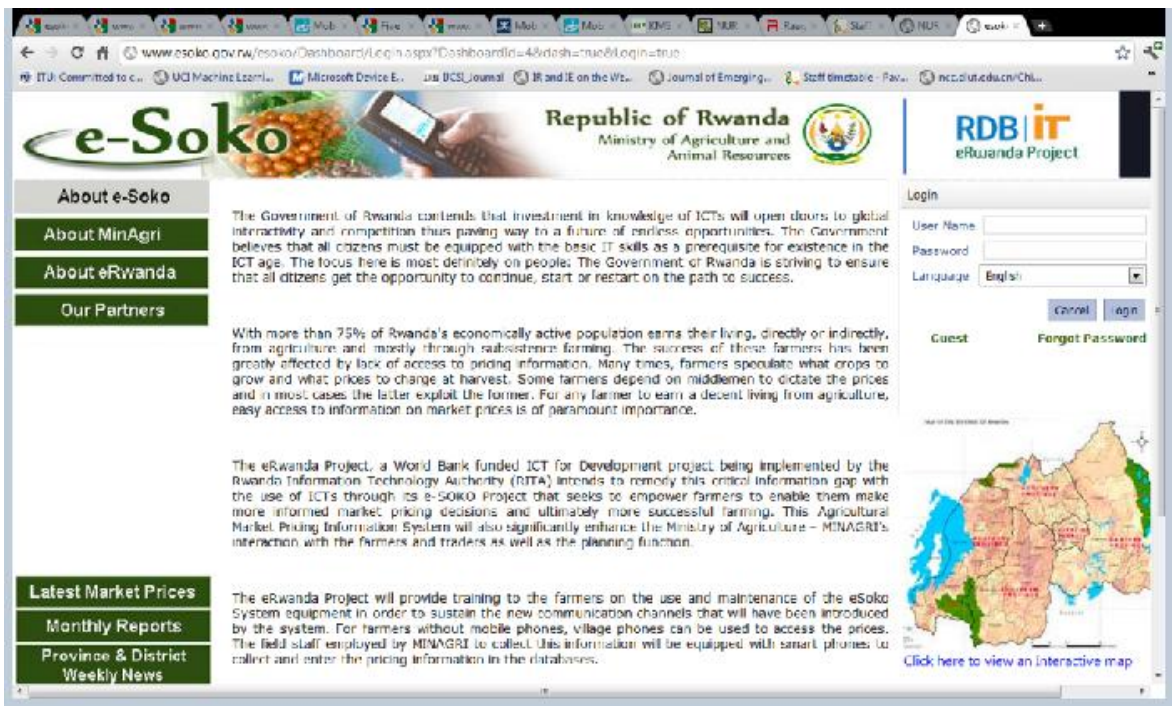

Figure 3: Webshot for e-Soko website home page

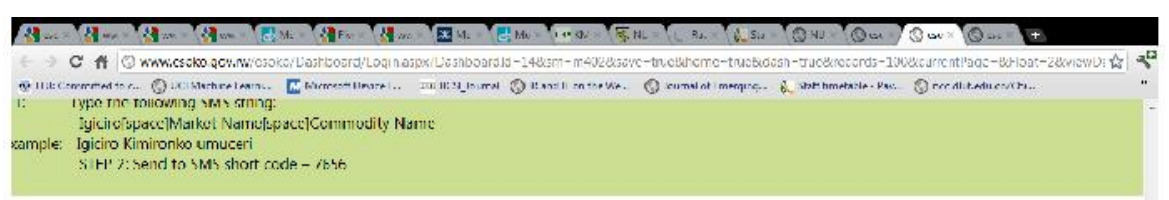

\begin{tabular}{|c|c|c|c|c|c|c|}
\hline \multirow[b]{2}{*}{ Code } & \multicolumn{3}{|c|}{ Commodities Names } & \multirow[b]{2}{*}{ Code } & \multicolumn{2}{|c|}{ Markets Names } \\
\hline & commodity Name & Code & commodity Name & & Market Name & Code \\
\hline 7 & Anasaka & 26 & ifu-ingeno & 101 & Kicukiro & 101 \\
\hline 8 & Amachasa & "is & gitnki & $10 \%$ & Nyabuggegn & 401 \\
\hline$s$ & Amiastiu & 30 & :Itrinck: & 103 & Snniisroke & 403 \\
\hline & Amatunda & 33 & Imyumbati & 201 & Kayenzi & 101 \\
\hline 11 & I $3 n \mathrm{P}$ & $3 x$ & Iาตุลาo & 3) & Muhanga & 205 \\
\hline 14 & Dilane & 40 & instyouslypu & 203 & Dularte & 406 \\
\hline 16 & :bigori & 18 & NPR & 201 & Nyonza & 107 \\
\hline $1 i$ & thijumba & is & soya & 00 & Ndaqn & ONK \\
\hline 19 & :tirysyi & 55 & Uturingolws & 200 & Mustris & 501 \\
\hline 20 & Ibishyimbo & 56 & Umuceli-Ásia & 207 & Gikongoro & 502 \\
\hline$n$ & ilininguru bituhura & si & Umuesli kw & 307 & sace & sas \\
\hline 2) & Ilu ibiguri & 58 & Unuscli $T_{2}$ & 302 & Dyuritiva & 504 \\
\hline \multirow[t]{4}{*}{25} & I'u-inyumbati & 59 & Uree & 303 & Caseke & 505 \\
\hline & & & & 40,6 & Rusinashi & $90 \mathrm{~h}$ \\
\hline & & & & 300 & Ruyarartia & 507 \\
\hline & & & & 306 & Musanze & 508 \\
\hline
\end{tabular}

Figure 4: e-Soko commodities and market details - Webshot 

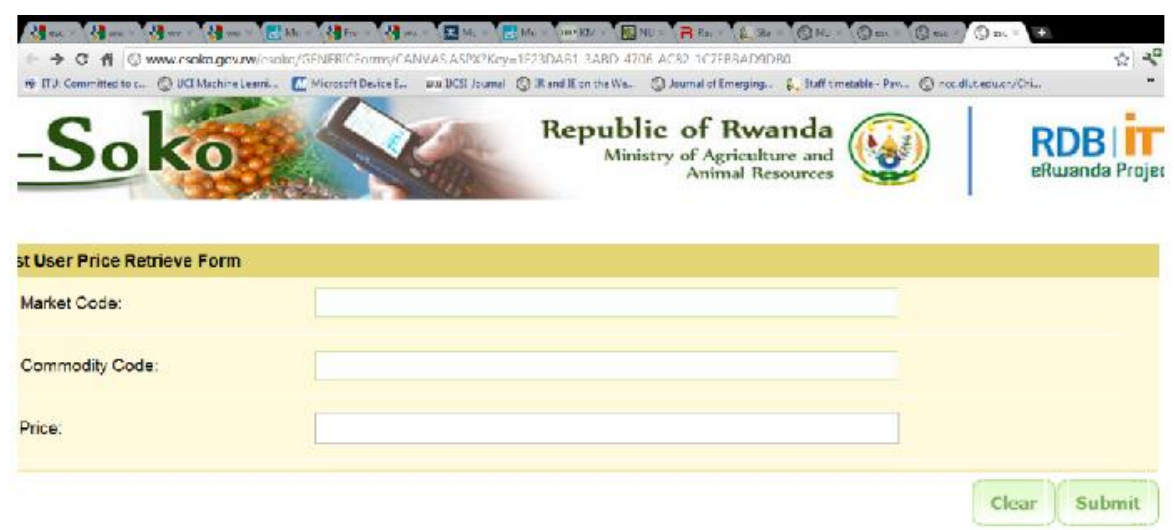

Figure 5: Market price Retrieve Form - Webshot

\section{Methods}

This paper is based on the primary data and secondary data. Focused Group Discussions, interviews and observations are the methods used for primary data collection. Apart from these mthods. various documents were examined and analysed on this topic from different sources mainly the internet, the government of Rwanda, WHO, UNDP, UNIFEM, World Bank.

\section{i. Group Focus discussions with Executive level officials}

Focused Group Interviews were held with the executive level officials - officials from District Administration, Huye District, and a senior member from Ministry of Agriculture. The discussions revealed that though the project has been implement during 2009, popular usage and awareness about the project is comparatively less than the expectations. Out of the five respondents, only two respondents ie., 40 percent were having the capability of providing the clear information about the projects. While inquiring about initiatives towards increasing the reach of the project, the respondents' opinion was that, the village level representatives were selected for the training.

\section{ii. MTN Mobile service providers}

Questionnaires were administered and observations are made on the service provider MTN mobile. A group of 20 staff from MTN mobile service, wanda were selected and distributed with questionnaires and asked to fill-in. 
The data analysis revealed that $100 \%$ of the respondents indicated that MTN services are helping optimally to improve the egovernance ie., information and service deliveries of Government of Rwanda. The ways of delivering the data to the needy were facilitated $5 \%$ of internet usages and $85 \%$ of mobile communications. Majority of the respondents positively approved the services offered which ultimately has a positive impact on the lives of the citizens.

\section{iii. Focused Group Discussions with Farmers}

A small sample of 10 farmers who belonged to farmer associations for the products like coffee, tea, banana, and sorghum were questioned about the impact of e-Soko in their agriculture processes. Only $10 \%$ responded positively about e-Soko. Though, the majority of the respondents agree that a technology like e-Soko will certainly bring benefits to them, but they were not aware about the project. Although other agricultural projects initiated by Ministry of Agriculture like GIRINGA project, were having the reach, the technicalities of these ICT enabled projects did not make it easy for the farmers who are mostly ICT illiterates to adopt and embrace them.

According to Wilson Muyenzi, Coordinator, eRwanda, the Government intends to distribute 3,500 mobile phones to farmers through cooperatives. At least one cooperative in every district has been identified to benefit from the project. The project to distribute mobile phones is also in line with government's intention of bridging the information gap between farmers and buyers. The first three to six months farmers will call free of charges, thereafter a subsidized price will be set. Government will pay 50 percent of the cost of the handset, MTN 25 percent and beneficiaries 25 percent.

The fiber Optic Connectivity and submarine cable connection provides highly speedy connectivity. Already the village level representatives and few selected individuals from farmer associations were selected for training on the usage of eRwanda project. The boom of mobile communication and internet penetration in the last decade is an encouraging factor that shows the e-readiness of Rwanda. The already $t$ available infrastructures for delivery of the health services to the people like TRACNet, NICI I infrastructure development etc., gives hope that, these existing infrastructure could be utilized and intertwined with these agricultural services. 


\section{Results and Discussions}

From the data analysis it is evident that, the Government of Rwanda has been seriously implementing ICT led development projects for the socioeconomic development of the country. Many initiatives such as delivering the services of the health sector through mobile phones, a mobile phone based information system for students to access their national examination results, rapid SMS service that uses mobile to ask questions as a means of reporting. The strong ICT policy of the government, government's commitment to ICT use in most of its activities in order to facilitate the rapid social-economic development, vision 2020, and other opportunities in ICT infrastructure development like Regional Communication Infrastructure Project (RCIP), Kalisimbi Project, Kigali Metropolitan Network and Wibro Mobile Wimax Technology , Rwanda National Backbone Project, EASSY Project , National Data Center, Regional interconnectivity (MTN Rwanda, MTN Uganda, Safaricom, Vodacom, Com Burundi) paves the good way for the optimum development in these fields.

The study also reveals that though the government is ICT pro-government, the awareness about the government initiatives in the middle level and lower level is still need to be improved. Information flow gaps has been realized towards the bottom in the hierarchy.

The other bottlenecks identified are ICT illiteracy among farmers, non-easy accessibility and affordability of technology by the end-user, lack of awareness about the technology and lack of willingness to embrace the technology at the side of farmers, whereas the technical bottlenecks are the non-availability of relevant and localized content, contents of the website are static which needs to be changed as an interactive one and the localization of contents of the website. The interoperability with the implemented projects.

As this e-Soko project is still in its infant stage, the coverage of the study has been limited to Huye district only.

\section{Conclusion and Recommendation}

Having explored all the impacts of these projects eSOKO and AMIS, it is evident that the needed infrastructure is available, the information is also available, political willingness is also available, but the important thing that is lacking is the integration of these aspects for the ultimate output. The technical framework of project should be integrated with other facilities such as weather forecasting, crop prices, information on sowing seeds in a certain season, creating awareness on modern agriculture, marketing local products; interactions with other agriculturists and farmers, a forum for 
reporting and disseminating new agricultural developments. An intensive training and awareness creation in ICT to all the stakeholders of the agriculture should be initiated.

\section{References:}

1. A recent report from the Consultative Group on International Agricultural Research (CGIAR) 'Healing wounds', emphasizes the importance of agricultural development and research for recovery from natural disasters and human conflict. Documenting three decades of agricultural development work in forty-seven countries, the report highlights the role of agricultural development in Rwanda's recovery, 2005.

2. CIA. Rwanda. The World Factbook (2008). Available at https://www.cia.gov/library/publications/the-world-factbook/geos/ rw.html accessed on January, 2010.

3. Clement Uwajeneza \& Emmanuel Kabahizi (2010), Development of a framework for the strengthening of market information systems in Rwanda, Part of the One UN Funded Project: Enhancing National Market's Potential and linkages to EAC and CEPGL frameworks, Rwanda.

4. Cynthia Donovan et al , Michigan State University, October 2008, Agricultural Statistics in Rwanda: Key Aspects of Institutional Organization and Performance by Cynthia Donovan, Michigan State University, October 2008

5. Economist Intelligence Unit (2008), Rwanda Country Report, May 2008

6. http://allafrica.com/stories/201002040063.html accessed on October 2010.

7. http://www.minagri.gov.rw/index.php?option=com_content\&view=arti cle\&id $=173 \% 3$ Aagriculture-in-

$\underline{\text { rwanda\&catid }=128 \% 3 \text { Aagriculture } \& \text { Itemid }=28 \& \text { lang }=\text { en }}$ accessed on 11.10.2010.

8. Loveridge, Scott, Alastair Orr, and AbdoulMurekezi. (2007), Agriculture and Poverty in Rwanda: A Comparative Analysis of the EICV1, EICV2, and LRSS Surveys. By. Oxford, England: Oxford Policy Management, Michigan State University, and Natural Resources Institute.

9. New Agriculturist, - Country Profile- Rwanda,http://www.newag.info/country/profile.php? $\mathrm{a}=843$, accessed on October 2010.

10. Rosegrant, Mark W. Ringler, Claudia et al (2006), http://www. ifpri.org/publication/agriculture-and-achieving-millenniumdevelopment-goals accessed on 11.10.2010. 
11. Rwandan Ministry of Agriculture and Livestock (MINAGRI) and European Union, Project Market Information System (MIS). 2007. Market Survey Report. Kigali: Rwandan Ministry of Agriculture and Livestock (MINAGRI) and European Union.

12. Usengumukiza Félicien (2009), Overview of Rwanda's ICT Context, IPAR-Rwanda - A situational analysis study presented at National EGovernance Conference 2009.

13. World Bank (2008), Rwanda: ICT at a Glance, available at www.devdata.worldbank.org/ict/rwa_ict.pdf, accessed o January 28, 2010 . 